DedikasiMU (Journal of Community Service)

Volume 2, Nomor 4, Desember 2020

\title{
SLOGAN PEDULI LINGKUNGAN SEKOLAH
}

\author{
Ismail Marzuki ${ }^{1}$, Nur Fauziyah ${ }^{2}$, Andi Rahmad Rahim ${ }^{3}$, Sukaris ${ }^{4}$ \\ ${ }^{1}$ Dosen Program Studi PGSD, Universitas Muhammadiyah Gresik \\ ${ }^{2}$ Dosen Program Studi Pendidikan Matematika, Universitas Muhammadiyah Gresik \\ ${ }^{3}$ Dosen Program Studi Akuakultur, Universitas Muhammadiyah Gresik \\ ${ }^{4}$ Dosen Program Studi Manajemen, Universitas Muhammadiyah Gresik \\ Email: Ippm@umg.ac.id
}

\begin{abstract}
ABSTRAK
SDN Kedung Sumber terlek di desa Kedungsumber terletak di wilayah Kecamatan Balongpanggang Kabupaten Gresik.Salah satu masalah yang sering dilakukan di SD adalah tidak ada kepedulian yang lebih untuk tetap menjaga kebersihan lingkungan sekolah karena disebabkan oleh banyak faktor salah satunya yaitu membuang sampah sembarangan.Membuang sampah adalah sebuah kebiasaan.Kebiasaan membuang sampah sembarangan harus diubah menjadi kebiasaan yang baik dengan membuang sampah pada tempatnya dan pemisahan sampah juga dilakukan. Membangun kebiasaan yang baik memang sulit, tapi dengan adanya peringatan secara tertulis yang sering dilihat dan penanaman kebiasaan konsep dan pengertian yang jelas dan mudah akan membuat tetap diingat dan akan diterapkan setiap hari, oleh karena itu kami peserta KKN UMG membuat slogan yang harus di pahami dan dilakukan oleh semua anggota sekolah yaitu "LISA LABIL BUDI TOSA" yang merupakan singkatan dari "lihat sampah langsung ambil buang di tong sampah" yang harus dilakukan dan diterapkan di SDN Kedung Sumber agar mengurangi sampah yang berserakan di lingkungan sekolah. Kebiasaan dibentuk dari kegiatan berulang selama bertahun-tahun. Maka dengan melakukan kebiasaan penerapan slogan setiap hari, pasti akan terlihat perbedaan pada lingkungan sekolah.Kami melakukan sosialisasi kepada seluruh peserta untuk mengenal slogan tersebut dan mengajak untuk melukakan penerapan setiap hari dan guru membantu dan membimbing siswa siswi untuk melaksanakan slogan tersebut, maka kebersihan lingkungan sekolah akan tercipta.
\end{abstract}

Kata Kunci :Kebersihan, lingkungan sekolah, slogan. 
Volume 2, Nomor 4, Desember 2020

\section{PENDAHULUAN}

\section{A. Latar Belakang}

Kuliah Kerja Nyata $(\mathrm{KKN})$ adalah bentuk kegiatan pengabdian kepada masyarakat oleh mahasiswa dengan pendekatan lintas keilmuan dan sektoral pada waktu dan daerah tertentu. Tujuan dari Kuliah Kerja Nyata (KKN) adalah menumbuh kembangkan minat mahasiswa dalam mengabdikan ilmunya kepada masyarakat melalui karya-karya inovatif yang berkualitas. Dalam kegiatan KKN tersebut mahasiswa diharapkan bisa melakukan pengabdian kepada masyarakat setempat, dengan cara melalui pendekatan dan sosialisasi serta melakukan kegiatan- kegiatan yang positif bagi masyarakat. Dalam kegiatan KKN ini mahasiswa juga dapat mendapatkan pengalaman baru dan pembelajaran baru yang tidak diperoleh dalam bangku perkuliahan, sehingga dalam hal ini mahasiswa ditugaskan langsung terjun kepada masyarakat agar dapat menyelesaikan masalah yang ada pada desa setempat begitu pula dengan persoalan- persoalan yang terjadi.

Dalam KKN kali ini kami di beri kesempatan untuk melakukan KKN di desa Kedung Sumber salah satu desa yang terletak di kecamatan Balongpanggang- kabupaten gresik desa yang di mana mayoriatas masyarakatnya berkerja sebagai petani sawah dan ladang. Desa Kedung Sumber merupakan desa yang terletak diperbatasan Lamongan dan Gresik. Karena desa yang jarak nya jauh dari kota maka masyarakat Kedung Sumber membangun sekolah untuk para anak-anak agar bisa menimbah ilmu pendidikan di bangku sekolah dasar atau yang bisa di sebut dengan nama SD.

Pendidikan merupakan wadah atau tempat awal seorang peserta didik untuk menerima pembelajaran atau ilmu-ilmu yang baru dengan kongkrit, oleh sebab itu kami bertujuan memberikan suatu pembelajaran kedisiplinan dalam menjaga kebersihan lingkungan sekolah.Arti dari Kebersihan sendiri adalah keadaan bebas dari kotoran, termasuk di antaranya, debu, sampah, dan bau. Di zaman modern, setelah Louis Pasteur menemukan proses penularan penyakit atau infeksi disebabkan oleh mikroba, kebersihan juga bererti bebas dari virus, bakteria patogen, dan bahankimia berbahaya.

Lingkungan adalah kombinasi antara kondisi fisik yang mencakup keadaan sumber daya alam seperti tanah, air, energi surya, mineral, serta flora dan fauna yang tumbuh di atas tanah maupun di dalam lautan, dengan kelembagaan yang meliputi ciptaan manusia seperti keputusan bagaimana menggunakan lingkungan fisik tersebut. Lingkungan juga dapat diartikan menjadi segala sesuatu yang ada di sekitar manusia dan mempengaruhi perkembangan kehidupan manusia.Kita harus tahu tentang manfaat menjaga kebersihan lingkungan, karena menjaga kebersihan lingkungan sangatlah berguna 
untuk kita semua karena dapat menciptakan kehidupan yang aman, bersih,sejuk dan sehat.

Masih banyak lagi manfaat menjaga kebersihan lingkungan, maka dari itu kita harus menyadari akan pentingnya kebersihan lingkungan mulai dari rumah kita sendiri misalnya rajin menyapu halaman rumah, rajin membersihkan selokan rumah kita, membuang sampah pada tempatnya, pokoknya masih banyak lagi.

\section{B. Tujuan}

Lingkungan akan lebih baik jika semua orang sadar dan bertanggungjawab akan kebersihan lingkungan, karena hal itu harus ditanamkan sejak dini, di sekolah pun kita diajarkan untuk selalu hidup bersih. Di agama islam pun kita di ajarkan untuk selalu hidup bersih, karena kebersihan adalah sebagaian dari iman.

\section{METODE PELAKSANAAN}

\section{A. Kerangkah pemecahan permasalahan}

Dalam sebuah dunia pendidikan jaman sekrang peserta didik di tuntut bukan hanya saja mampu dalam hal akademik melainkan juga non akademik, pelajaran non akademik adalah sebuah pelajaran yang lakukan di luar pembelajran jam efektif sekolah. Oleh sebab itu kami memberikan pembelajaran tentang kedispilan dalam menjaga kebersihan bertujuan utnuk menciptakan lingkungan sekolah yang bersih dan nyaman serta menanamkan nilai kepesulian terhadapa lingkungan sekolah.

Dalam pembelajaran yang kami lakukan ini terkadang sebagai masyarakat sering sekali meremehkan persolan tentang kepedulian terhadap kebersihan lingkungan sekolah. Bahkan menurut padangan kami para siswa atau semua anggota sekolah banyak yang tidak memeperhatikan kebersihan karena disekolah masih banyak sampah yang berserakan. Penyebab nya mungkin banyak faktor, jika siswa dan semua anggota sekolah bisa disiplin dalam menjaga kebersihan maka tidak ada lingkungan sekolah yang kotor. Peran orang tua atau keluarga juga salah satu faktor, apabila dalam didikan orang tua dan keluarga ada disiplin yang diterapkan dalam menjaga kebersihan maka siswa akan tetap menjaga kebersihan itu hingga disekolah.

Disiplin dalam menjaga kebersihan lingkungan sekolah bisa menggunakan banyak cara yag dilakukan, tapi kami mencoba untuk menggunakan penerapan slogan yang dilakukan oleh semua anggota sekolah.Penanaman dasar slogan "LISA LABIL BUDI TOSA" harus benar diterangkan agar semua anggota sekolah melaksanakan slogan tersebut dan akan tercipta ligkungan sekolah yang bersih dan nyaman.Kami juga ada tambahan agar slogan ini bisa terlaksana dengan maka kami memberikan sedikit ilmu 
tentang pemisahan sampah organic dan anorganik. Kami juga meberikan tempat sampah kepada semua kelas agar bisa dengan mudah untuk melakukan buang sampah dan melakukan pemisahan sampah. Siswa siswi memang sulit untuk menjalakan sebuah kegiatan yang awal untuk dilakukan atau asing,karena slogan ini merupakan kegiatan asing yang harus dilaksanakan oleh semua sisw dan siswi.Dengan demikian kami memberikan hadiah atau lomba kebersihan untuk diikuti semua kelas, dan memberikan hadiah kepada kelas yang terbaik dalam menjaga kebersihan nya.

\section{B. Kegiatan Pelaksanaan}

Waktu dan Tempat dalam Kegiatan Pembelajaran yang kami lakukan di SD di lakasanakan pada waktu :

- Hari : sabtu

- Tanggal :24-Agustus-2019

- Pukul : 09.00 wib - selesai

- Tempat : SDN Kedung Sumber kec. Balongpangang

\section{HASILDAN PEMBAHASAN}

\section{A. Hasil}

Kegiatan pembelajaran kedisiplinan : Penjelasan arti slogan dan cara untuk melaksanakan slogan, di lakukan dilapangan.

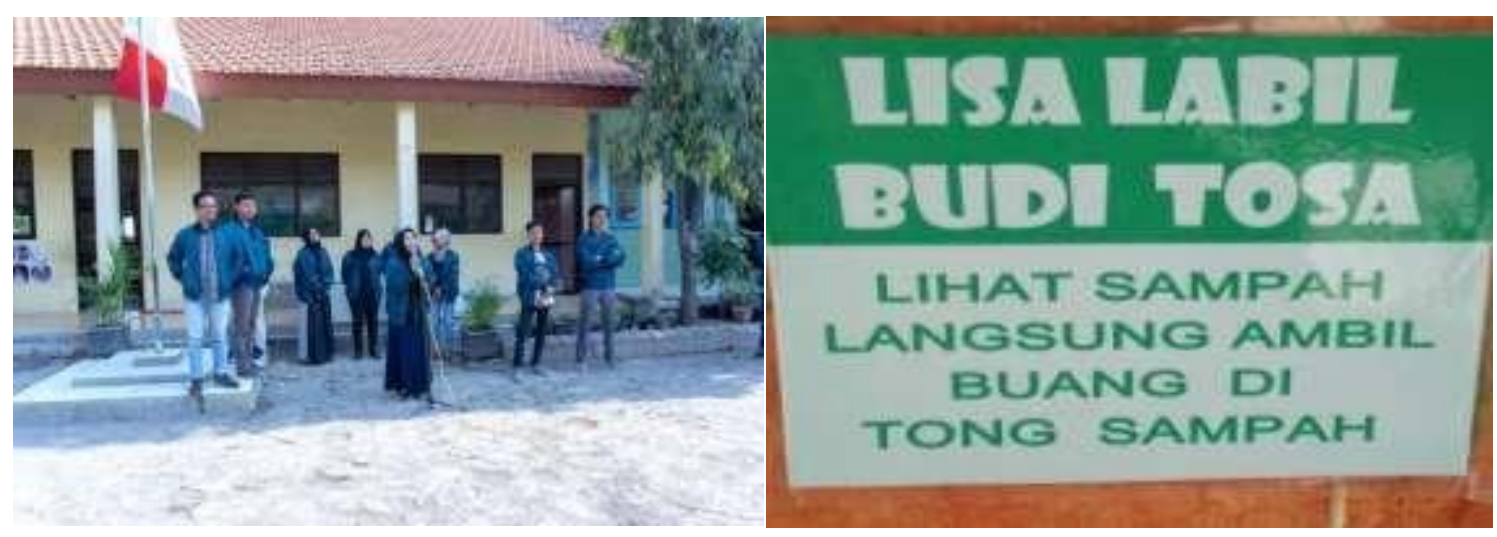

Gambar 1. Proses penerapan slogan 


\section{DedikasiMU (Journal of Community Service)}

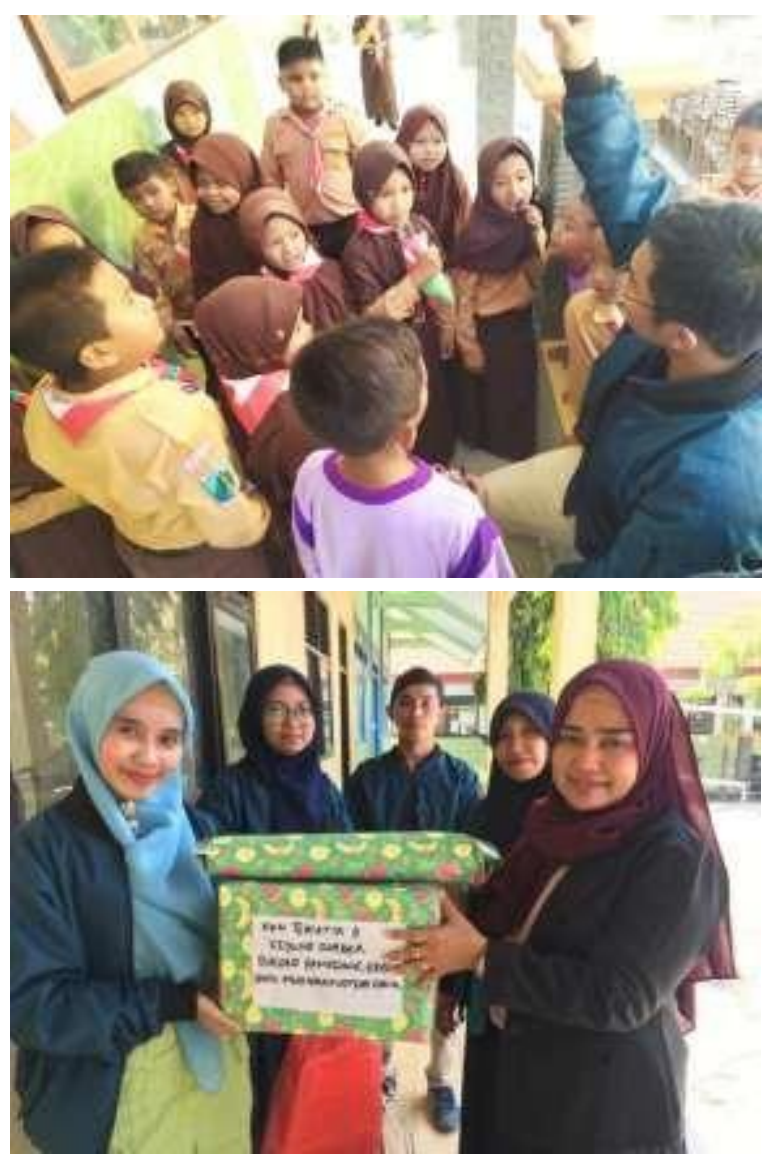

Gambar 2. Sosialisasi program ke murid sekolah dan Guru

\section{B. Pembahasan}

Dalam kegiatan pembelajaran disiplin dalam menjaga kebersihan lingkungan sekolah dengan penerapan slogan "LISA LABIL BUDI TOSA" .Pembelajaran ini kami berikan kepada peserta didik di SDN KEDUNG SUMBER agar peserta mampu menjaga lingkunga sekolah sehingga tercipta sekolah yang bersih dan nyaman. Apabila lingkungan sekolah yang nyaman dan bersih maka akan terjadi pemebelajaran sekolah yang efektif dan lancar tanpa adanya gangguan dari faktor kebersihan misanya sampah berserakan atau yang lainnya.Menanamkan sikap kepedulian terhadap lingkungan sekolah yang dimulai dengan penerapan slogan "LISA LABIL BUDI TOSA". Oleh sebab itu melakukan kegiatan pembelajaran non akademik juga sangat penting untuk bekal peserta didik. 
Volume 2, Nomor 4, Desember 2020

\section{KESIMPULAN DAN SARAN}

\section{A. Kesimpulan}

Dari kegiatan ini dapat di simpulkan bahwa kami memberikan materi pembelajaran pentingnya kebersihan lingkungan sekolah yang menggunakan penerapan kebiasaan dengan media slogan. Materi kegiatan ini kami lakukan dengan sosialisasi seara langsung dilapangan engan semua anggota sekolah. Kami berharap agar nanti peserta didik dan semua anggota sekolah tetap melakukan penerapan slogan untuk menjaga lingkungan sekolah.

\section{B. Saran}

Bagi para orang tua di jaman sekarang agar alangkah baiknya jika bisa memberikan kebiasaan - kebiasaan positif di lingkungan rumah, bertujuan agar anak tersebut bias mengubah kebisaan negative dengan mudah karena sudah dilakukan terlalu sering.

\section{DAFTAR PUSTAKA}

Employment Research Institute. (2005). Pelatihan Public Speaking. Jurnal Bakti Masyarakat Indonesia, ISSN 2620-7710 (Versi Cetak) Vol. 2, No. 1. Hal. 117-122. Mulyana, D, (2005). Ilmu Komunikasi: Suatu Pengantar. Bandung Remaja Rosdakarya. 